Annals of Plant Sciences

ISSN: 2287-688X

OPEN ACCESS

Research Article

www.annalsofplantsciences.com

\title{
Phytochemical screening, antibacterial and antifungal activity of Pinda concanensis (Dalzell) P.K. Mukh. \& Constance (Apiaceae) an endemic plant from Nasik district (M.S.) India
}

Thakur Hemantkumar A.

Post Graduate \& Research Center of Botany, Gokhale Education Society's, H.P.T. Arts \& R.Y.K. Science College Nasik-422005, Maharashtra State, India.

Received: 2017-11-14; Revised: 2017-11-20; Accepted: 2017-11-27

\begin{abstract}
Medicinal plants are a source of great economic value all over the world. Various medicinal plants have been used for years in daily life to treat diseases. Present study illustrates the phytochemical screening and antimicrobial activity of Pinda concanensis (Dalzell) P.K. Mukh. \& Constance. The selected plant Fruits were collected and powdered. The bioactive compounds were extracted by using Methanol, Ethanol, Petroleum ether and water in a soxhlet extractor. The antimicrobial activity was determined by using agar disc and well diffusion method. Acetone and chloroform extracts were mixed with $1 \mathrm{ml}$ diethyl sulfoxide (DMSO) and added into the well. The extract of Methanol with Pinda concanensis (Dalzell) P.K. Mukh. \& Constance has shown maximum zone of inhibition against bacterial pathogens when compared to chloral and water extract. Phytochemical analysis reflected the antimicrobial activity of Pinda concanensis (Dalzell) P.K. Mukh. \& Constance which is due to the presence of phytochemical compounds like alkaloids, terpenoids, steroids, flavonoids, Saponins, Phenolic compounds and tannins. The results of agar well diffusion method indicated the inhibition and it depends largely upon plant parts used and organism tested.
\end{abstract}

Keywords: Pinda concanensis, Phytochemical constituents, Antimicrobial activity.

\section{Introduction}

Plant have been an integral part of life in many local communities for food and fringe to mainstream use with a great number of people seeking remedies and health approaches free from seeking side effect caused by synthesis chemical (Dubey N.K...et al., 2004). Worldwide over $80 \%$ of the people depend on medicinal plant species to meet their day today health care (WHO, Geneva, Switzerland; 2002). Plants are fundamental source for all other living organism.

Pinda concanensis (Dalzell) P.K. Mukh. \& Constance is commonly known as Konkan pinda in marathi called 'pand'. Though this species is endemic only to Maharashtra state, it has been categorised into low risk because it is one of the most common herb throughout the Western Ghats. The tuber of this plant is edible. This plant is found in Nashik district, Anjaneri hill, The Apiaceae (Umbelliferae) is one of the best-known plant families with peculiar botanical characters such as the typical umbellate inflorescences and the specialized dry fruits splitting into two one-seeded mericarps. They are widely distributed in temperate climate regions where they often are used along with spices or drugs in cough due to the presence of useful secondary metabolites such as coumarins, essential oils and sesquiterpenes. The family Apiaceae (Umbelliferare) is represented by about 3540 species in the world while in India it comprises about 240

*Corresponding Author:

Dr. Hemantkumar A. Thakur,

Post Graduate \& Research Center of Botany,

Gokhale Education Society's H.P.T. Arts \& R.Y.K. Science College,

Nasik-422005, Maharashtra State, India.

E-mail: hemant13570@gmail.com species. As the genus Pinda is monotypic belongs to family apiaceae, it is represented by only species i.e. Pinda concanensis (Dalzell) P.K. Mukh. and Constance. It is endemic to Northern Western Ghats of India. The tuberous roots are eaten as row by local folklore. Pinda is an annual herb with tuberous roots, grows upto 1-2 feet in high, commonly known as Kokan pinda. This narrow endemic and locally used plant species is evaluated for the first analysis of the essential oil. This work boosts the biodiversity of aromatic plants for their medicinal as well as dietary properties. (Patil et al., (2016)

\section{Plant Morphology}

Pinda concanensis (Dalzell) P.K. Mukh. \& Constance is a herb. $40-120 \mathrm{~cm}$ height erects, sparsely branched above, hirsute to hispidulous. Leaves ternate-pinnate or bipinnate; leaflet ovate-lance late to ovate, serrate and often lobed; carline leaves reduced upward, the uppermost often reduced to oblong-oval, bladeless sheath. Peduncles $2-10 \mathrm{~cm}$ long, or same times abortive; rays usually 4-10, 1-5 $\mathrm{cm}$ long, hispidulous; umbel lets 6-12-flowered; mature pedicels $2-5 \mathrm{~mm}$ long. Calyx teeth small, ovate. Petals oval with a narrower inflexed apex, white with colored veins. Fruits strongly compressed dorsally, oval or elliptic, rounded at base and apex. Flowering and Fruiting occurs generally in July-August. 


$\begin{array}{cl}\text { Systematic Position } & \\ \text { Kingdom } & \text { : Plantae } \\ \text { Division } & \text { : Magnoliopsida } \\ \text { Order } & : \text { Apiales } \\ \text { Family } & : \text { Apiaece } \\ \text { Genus } & : \text { Pinda } \\ \text { Species } & \text { : concanensis }\end{array}$

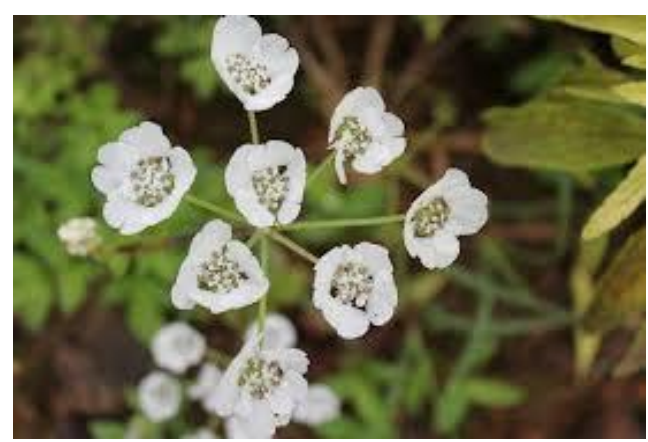

Figure: Pinda concanensis (Dalzell) P.K. Mukh. \& Constance

Among these Karnataka, Pinda, Polyaygus, Sivadasania and Vanasushava are endemic to the Western Ghats of India (Irwin and Narasimhan, 2011; Monahan and Pimento, 2007). Pinda concanensis (Dalzell) P. K. Much. \& Constance was under the genus Heraclea Pinda is Vanasushava and Pinda shares common characters in irregular petals and fruit anatomy (Caquet-Marc, 1977), leaf surface (Guyot, 1978), photochemistry (Car bonnier and Molto, 1977) and pollen morphology (CerceauL'arriva et al., 1977). Cytological studies in Four Endemic Genera of Apiaceae from India (K. V.C. Gosawi et al., 2016). Patil S.V et al., (2016) extracted essential oil by LCMS analysis, thirty compounds were identified from the essential oil extracted from seeds of Pinda concanensis. Swarnalatha \& et al., (2009) investigated the antibacterial nature of this plant and suggests that this plant could be exploited in the management of diseases caused by the tested bacteria in human. Further ethanolic extract of Spheranthus amaranthoides in graded doses reduced diarrhoea and thereby lending supportto use Spheranthus amaranthoides in folklore medicine against chronic diarrhea. The phytochemical analysis revealed that the active principle, a phenolic compound present in the ethanolic extract of Spheranthus amaranthoides, is thus responsible for the antibacterial and antidiarroheal activity. It has become expedient to examine scientifically the protective effects of these herbal plants and thus there has been a continuing search for new and more potent antibiotics (Heisig, 2001). Basarkar \& Shinde (2012) investigated phytochemical analysis of Leonotis nepetaefolia.

Pinda concanensis (Dalzell) P. K. Mukh. \& Constance and Vanasushava pedata (Wight) P.K. Mukh. \& Constance were initially treated under the genus Heracleum; however, based on morphological characters, Mukherjee and Constance transferred $H$. concanense Dalzell into Pinda (Mukherjee and Constance, 1974) and $H$. pedatum Wight into Vanasushava (Mukherjee and Constance, 1986a). Both Pinda and Vanasushava are of rare in occurrence (Nayar, 1996; Mukherjee, 1988). Mohanan and Pimenov (2007) raised Peucedanum josephianum Wadhwa \& H.J. Chowdhery into a separate monotypic genus Sivadasania on the basis of subterete to slightly laterally compressed fruit and equally keeled mericarp ribs. There is ample literature on preliminary phytochemical surveys and the knowledge of chemical constituents of plants is desirable to understand herbal drugs and their preparations. Most importantly, these studies will be helpful to isolate and characterize the chemical constituents present in those plant extracts. In addition, the knowledge of chemical constituents of plants would further be valuable in discovering the actual value of folkloric remedies (Farnsworth, 1966)

\section{Materials and Methods}

The dried fruits of Pinda concanensis (Dalzell) P.K. Mukh. \& Constance collected from Anjneri hills of Nasik District. The plant material (fruits) is sun dried and was powdered. The powder used for plant extract by using different solvent like Ethanol, Methanol, Petroleum ether and Distilled water is by Soxhlate apparatus method. The plant extracts used for Qualitative phytochemical analysis. The phytochemical are essential to metabolism and chemical processes of plant body. The phytochemical are studied are alkaloids, terpenoids, steroids, flavonoids, glycosides, tannins and Saponins. Al these compounds have does have diverse beneficial activity which depends on molecular structure of the substance

\section{Phyochemical Test}

The test were to find the presence of active chemical such as alkaloids, terpenoids, carbohydrates, amino acids and proteins, phenol compounds, steroids by the following procedure.

\section{1.) Alkaloids}

Detection of alkaloids: - solvent free extract, $50 \mathrm{mg}$ is stirred with few $\mathrm{ml}$ dilute hydrochloric acid and filtered. The filtered is tested carefully with alkaloid reagent as follows:-

\section{A. Mayer's test (Evans, 19197)}

A few $\mathrm{ml}$ of filtrate, a drop or two of Mayer's reagent are added by the side of test tube. A white or creamy precipitate indicates the test is positive.

Mayer's reagent: - mercuric chloride (1.358) is dissolved in $60 \mathrm{ml}$ of water and potassium iodine (5.og) is dissolved in $10 \mathrm{ml}$ of water. The two solutions are mixed up to $100 \mathrm{ml}$ with water.

B. Wagner's (Wagner, 2004): To a few $\mathrm{ml}$ of filtrate, few drops of Wagner's reagent are added by the side of the test tube. A reddish-brown precipitate confirms the test as positive. 
Detection of Carbohydrates and Glycosides:The extract $(100 \mathrm{gm})$ is dissolved in $5 \mathrm{ml}$ of water and filtered.The filtered is subjected to the following test.

A. Barrfoed's test: To $1 \mathrm{ml}$ of filtered, $1 \mathrm{ml}$ of Barrfoed's reagent is added and heated on a boiling water bath for $2 \mathrm{~min}$. Red precipitate indicates presence of sugars.

Barrfoed's Reagent: - Copper acetate, 30.5gm is dissolved in $1.8 \mathrm{ml}$ of glacial acid.

Benedict's Test:- To $0.5 \mathrm{ml}$ filtrate, $0.5 \mathrm{ml}$ of Benedict's reagent is added. The mixture is heated on a boiling water bath for $2 \mathrm{~min}$. A characteristic red -brown colour precipitate indicates the presence of sugar.

B. Iodine Test: - to $3 \mathrm{ml}$ of the aqueous extract was added about $1 \mathrm{ml}$ of iodine solution. A purple colour at the interphase indicates the presence of carbohydrate.

C. Keller Kiliani Test:- $2 \mathrm{ml}$ of extract was dissolved in $2 \mathrm{ml}$ of Glacial acetic acid containing one drop of ferric chloride solution . the mixture was then poured in to the test tube containing $1 \mathrm{ml}$ of concentrated sulphuric acid. A brown ring at the interphase indicates the presence of deoxe sugar.

Detection of Saponins : - the extract $(50 \mathrm{mg})$ is diluted with distilled water and made up to $20 \mathrm{ml}$. The suspension is shaken in a graduated cylinder for 15 min. a two-cm layer of foam indicates the presence of Saponin.

Detection of Proteins and Amino Acids:- The extract $(100 \mathrm{mg})$ is dissolved in $10 \mathrm{ml}$ of D.W and filtered through Whitman No.1 filter paper and the filtrate is subjected to test for proteins and amino acid.

A.Million's Test: The two $\mathrm{ml}$ of filtrate, few drops of Million's reagent are added. A white precipitate indicates the presence of proteins and amino acid.

B. Ninhydrin's test: Two drops of ninhydrin solution (10 mg of ninhydrine in $200 \mathrm{ml}$ of acetone) are added to two $\mathrm{ml}$ of aqueous filtrate. A characteristic purple colour indicates presence of amino acids.

Detection of Phenolic Compounds and Tannins

A. Chloride Test:- The extract (50mg) is dissolved in $5 \mathrm{ml}$ of D.W.To this, few drops of neutral $5 \%$ ferric chloride solution are added .A dark green colour indicates the presence of Phenolic compound.

\section{Detection of Gum and Mucilage}

The extract $(100 \mathrm{mg})$ is dissolved in $10 \mathrm{ml}$ of D.W. and to this $25 \mathrm{ml}$ of absolute alcohol is added with constant stirring. White cloudy precipitate indicates the presence of gums and mucilage.

Glycoside: Glycoside are compounds which upon hydrolysis give rise to one or more sugars and compounds which is not a sugar. To the solution of the extract in glacial acetic acid, few drops of ferric chloride and concentrated sulphuric acid and observe for reddish brown coloration at the junction of two layers and the bluish green colour in the upper layer.

Terpenoids and Steroids: - $4 \mathrm{mg}$ of extract was treated with $0.5 \mathrm{ml}$ of chloroform. Then concentrated solution of sulphuric acid was added slowly and red violet colour for steroids.

Tannins: - To $0.5 \mathrm{ml}$ extract solution $1 \mathrm{ml}$ of water and 1-2 drops of ferric chloride solution was added. Blue colour was observed for Gallic tannins and black colour for catecholic tannins.

Fixed Oils and fats: a) A small quantity of extracted is passed between two filter paper. Oil stain on filter paper indicated the presence of mixed oil.

Saponification Test: - A few drops of $0.5 \mathrm{~N}$ alcoholic potassium hydroxide solution are added to a small quantity of extract along with a drop of phenolphthalein. The mixture is heated on water bath for two hours. Formation of soap partial neutralization of alkali indicates the presence of mixed oil and fats.

\section{Antimicrobial Activity of Plant Extract}

To study antimicrobial activity following four bacterial and one fungal Strain were used.

\section{Bacteria}

$$
\begin{array}{ll}
\text { a. } & \text { Staphylococcus aureus } \\
\text { b. Escherichia coli } \\
\text { c. }
\end{array}
$$

Fungi

a. Aspergillus niger
b. Aspergillus flavus

The bacterial isolates were cultured on nutrient agar and incubated at 37 for $24 \mathrm{hrs}$ and the microorganisms were repeatedly sub-cultured in order to obtain pure isolation. Morphological and biochemical reactions were carried to ascertain proper identification. They were inoculated into nutrient agar slants and stored 37degree Celsius. Overnight broth culture of the respective bacterial strains was adjusted to turbidity equivalent to 0.5 McFarland standards.

\section{Media preparation}

As per composition following media were prepared. PDA Medium (for fungi) and Nutrient agar medium (for Bacteria)

The antimicrobial assay was performed by following method:

Agar well diffusion method for solvent extract: The modified agar well diffusion method was employed Muller-Hinton agar plates were inoculated by streaking the swab over the entire sterile over the entire sterile agar surface. This 
procedure was repeated by streaking two more times, rotating the plate approximately $60^{\circ}$ each time to ensure even distribution of the inoculums to dry at room temperature, $6 \mathrm{~mm}$ - diameter well bored in the agar. Each extract was check for antimicrobial activity by introducing $100 \mu$ l of 4000 $\mu \mathrm{g} / \mathrm{ml}$ concentration into triplicate well simultaneously; and the dilution medium for the positive control was respective solvent. The plates were allow to stand at room temperature for $1 \mathrm{hr}$. for extract to diffuse into the agar and then they were incubated at $35 \pm 2{ }^{\circ} \mathrm{C}$ for $24 \mathrm{hr}$. solvent extract were showed area of inhibition that solvent extract further analyzed for find out minimum inhibition concentration (MIC) by using $25 \mu \mathrm{l}, 50 \mu \mathrm{l}, 75 \mu \mathrm{l}$ and $100 \mu \mathrm{l}$ against positive control used pure solvent $100 \mu 1$. The plates were allowed to stand at room temperature for $1 \mathrm{hr}$ for extract to diffuse into the agar and then they were incubated at $35 \pm 2 \circ \mathrm{C}$ for $24 \mathrm{hr}$. Zone of inhibition measured with scale in $\mathrm{mm}$ and observation were noted in notebook.

\section{Results and Discussion}

The fruits of plant Pinda concanensis (Dalzell) P.K. Mukh. \& Constance were subjected to extraction with Ethanol, Methanol, Pet. Ether, And Distilled water respectively. Result of phytochemical properties is showed in table 1. phytochemical studies of different crude extract shows presence of Alkaloids, Carbohydrates, Steroids, Saponin, Tannin and phenol etc. is shown in table 2.

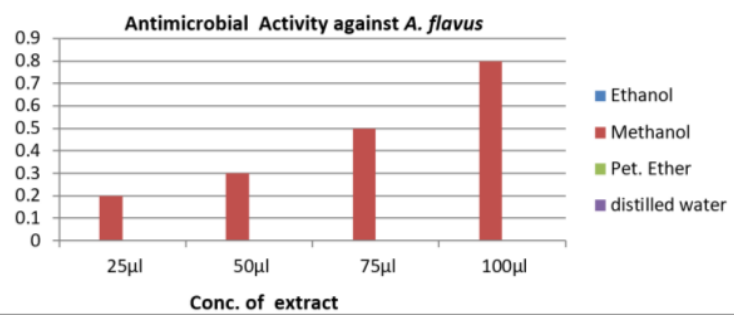

Fig. 1.4. Graphical representation showing Antimicrobial activity against $A$. flavus

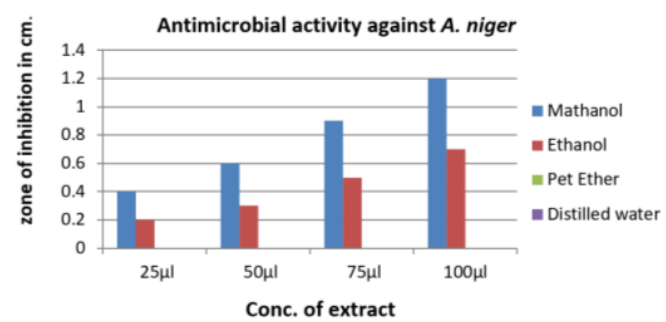

Fig. 1.5. Graphical representation showing Antimicrobial activity against A. niger

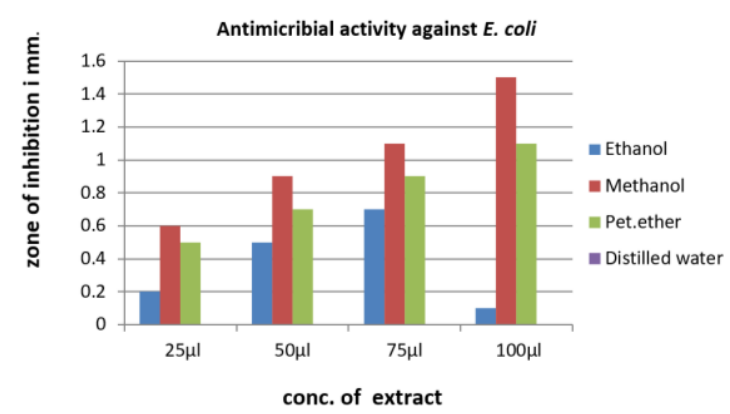

Fig. 1.6. showing Graphical representation of Antimicrobial Activity of E. coli

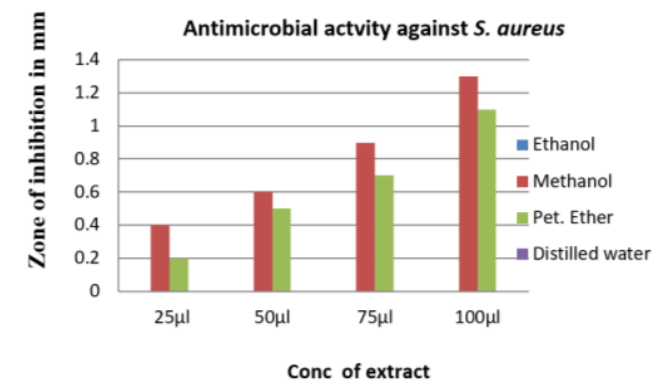

Fig. 1.7. showing Graphical representation of Antimicrobial Activity against $S$. aureus
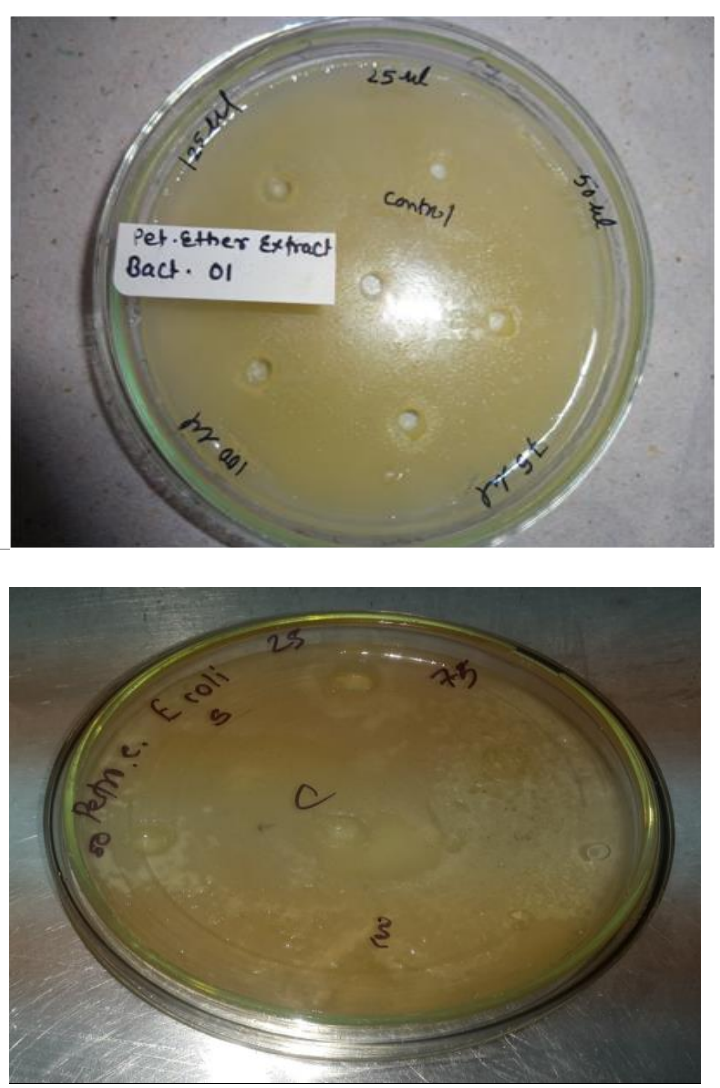

Antibacterial activity showing inhibition zone. 

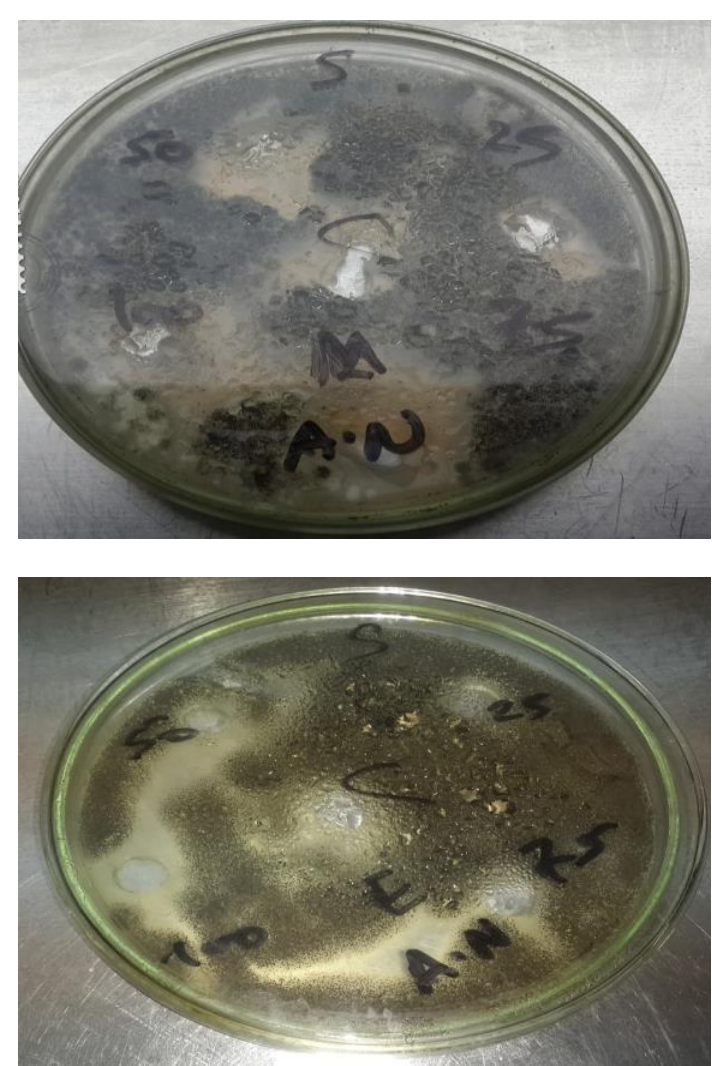

Antifungal activity showing inhibition zone against $\boldsymbol{A}$. niger

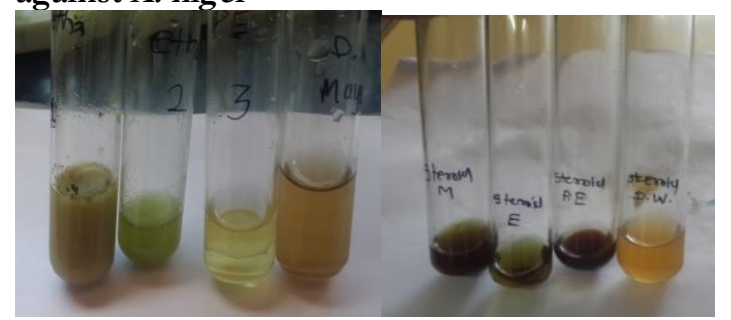

Mayrers Test

Steroid test

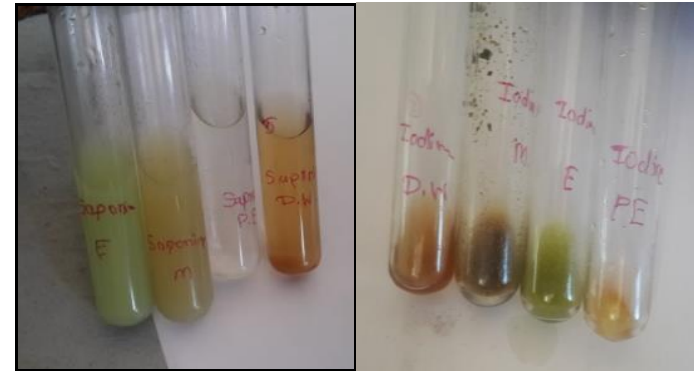

Result showing presence of Saponin result showing presence of Iodine

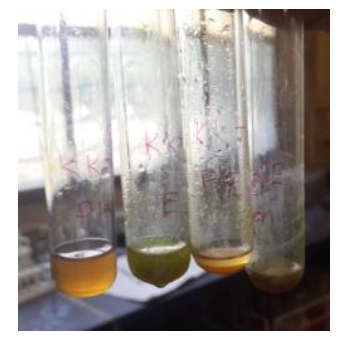

Result showing presence of glycoside

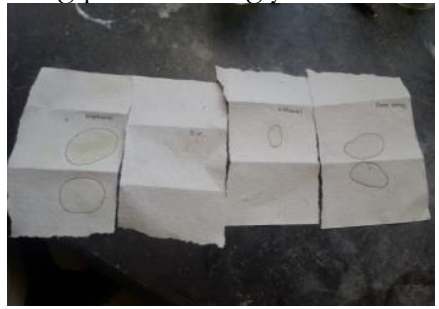

Result show presence of fat \& oil.

Table 1. Physiological characteristics of different Extract of Pinda concanensis (Dalzell) P.K. Mukh. \& Constance

\begin{tabular}{lllll}
\hline Solvent & $\begin{array}{c}\text { Initial } \\
\text { weight of } \\
\text { powder } \\
\mathbf{( g m )}\end{array}$ & $\begin{array}{c}\text { Final } \\
\text { weight of } \\
\text { powder } \\
\mathbf{( g m )}\end{array}$ & $\begin{array}{c}\text { Weight } \\
\text { of crude } \\
\text { extract } \\
\mathbf{( g m )}\end{array}$ & $\begin{array}{c}\text { Colour of } \\
\text { Extract }\end{array}$ \\
\hline Distilled water & 10 & 9.20 & 0.80 & Brown \\
Methanol & 10 & 9.17 & 0.83 & Green \\
Ethanol & 10 & 9.34 & 0.66 & Light green \\
Pet. Ether & 10 & 9.43 & 0.57 & Pale green \\
\hline
\end{tabular}

Table 2. Preliminary phytochemical analysis of crude extract of Pinda concanensis

\begin{tabular}{|c|c|c|c|c|c|}
\hline Sr No. & Phytochemical Test & Distilled Water & Ethanol & Methanol & Petroleum ether \\
\hline \multirow[t]{3}{*}{1.} & Alkaloids Test & & & & \\
\hline & a. Mayer's Reagent & ++ & + & + & + \\
\hline & Wagner's Reagent & ++ & + & + & + \\
\hline \multirow[t]{5}{*}{2.} & Carbohydrate & & & & \\
\hline & Barrfoed's Test & - & - & - & - \\
\hline & Benedict's Test & - & - & - & - \\
\hline & Iodine Test & _ & _ & _ & _ \\
\hline & Keller- Killani Test & $\overline{+}$ & - & $\overline{+}$ & - \\
\hline 3. & Detection of Saponin & _ & - & + & - \\
\hline \multirow[t]{3}{*}{4.} & Detection of protein And Amino Acids & & & & \\
\hline & Million’s Test & + & + & + & + \\
\hline & Ninhydrin Test & + & - & - & + \\
\hline \multirow[t]{2}{*}{5.} & Detection Of Phenolic Compound And Tannins & & & & \\
\hline & Ferric chloride Test & _ & _ & _ & + \\
\hline 6 & Detection Of Gum And Mucilage & ++ & +++ & + & _ \\
\hline 7 & Glycoside test & + & - & + & - \\
\hline 8 & Terpenoids And Steroids & _ & - & + & + \\
\hline 9 & Tannins & + & + & _ & + \\
\hline 10 & Mixed Oils And Fats & & & & \\
\hline \multirow[t]{2}{*}{11} & a. Saponification Test & ++ & + & ++ & + \\
\hline & Spot tests & + & + & + & _ \\
\hline
\end{tabular}


Table 3. Antimicrobial Activity of Pinda concanensis fruit

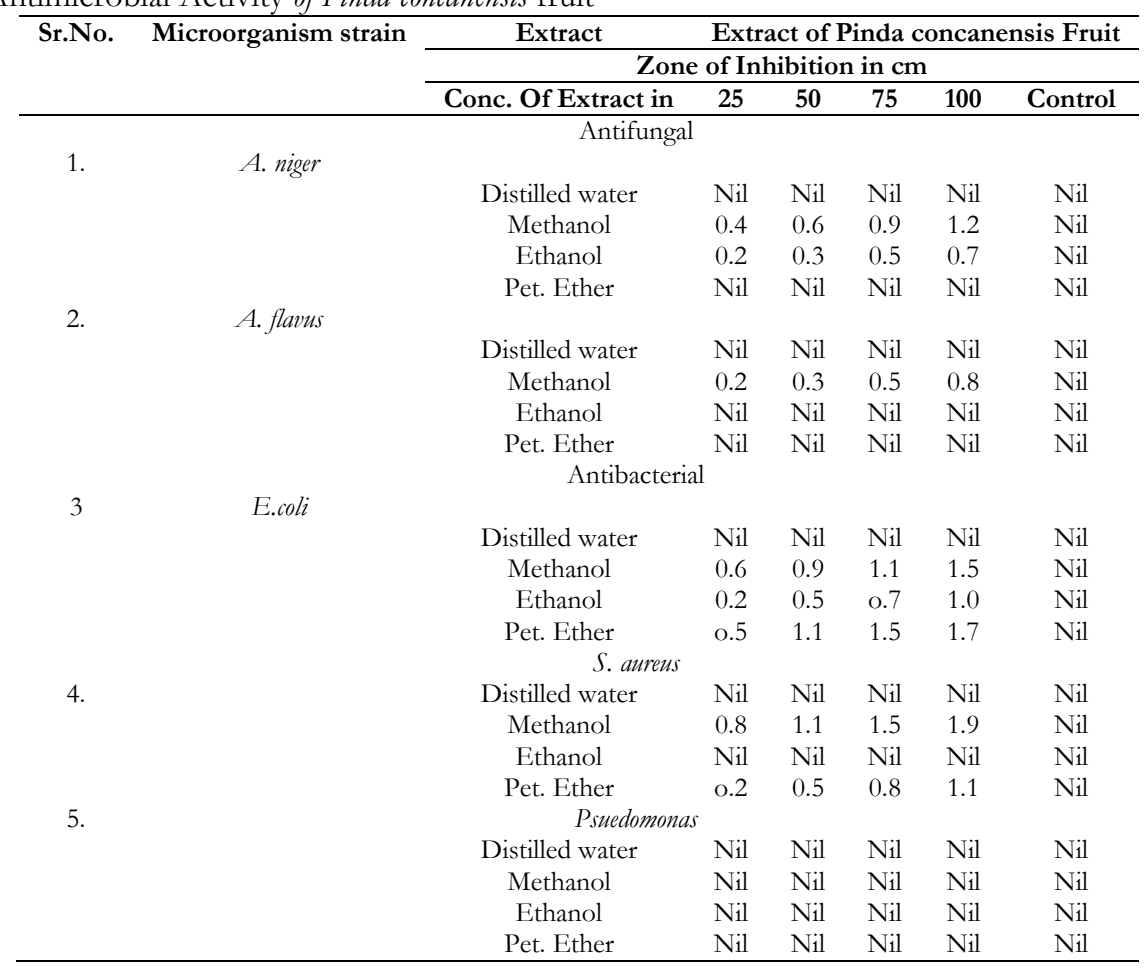

All plant material extract showed presence of Alkaloid, Protein and amino acid. Carbohydrates present in methanol \& pet. Ether extract only. Fixed oil and volatile oils are strongly present in all solvent except distilled water. Glycosides \& steroids are strongly present in pet. Ether extract. The phytochemical detected in the various extracts are contains the bioactive compounds.

Pinda concanensis (Dalzell) P.K. Mukh. \& Constance fruit powder extracted in Methanol, Ethanol, Pet. Ether, \& Distilled water tested against Fungi and pathogenic bacteria table 3 out of this the A. niger shows inhibition zone in ethanol and methanol. E. coli shows more inhibition zone in all extract except distilled water. Pseudomonas bacteria do not show any activity and inhibition zone.

Pinda concanensis (Dalzell) P.K. Mukh. \& Constance fruit powder sequentially extracted in methanol, ethanol Pet. Ether and water extracts were further taken for antimicrobial activity and were tested at $25,50,75$, and $100 \mu \mathrm{l}$ for each of the extract with reference to pure solvent as control. The organism taken were two fungal strain and three bacterial strain i.e. Aspergillus niger, Aspergillus flavous, Escherichia coli, Staphylococcus aureus and Psuedomonas

Antimicrobial activity was observed against E.coli and Aspergillus niger.100 $\mu$ methanol extract showed the maximum inhibition for the above organism. But water extract and ethanol extract did not show maximum impact in inhibition. The result of this study validates the use of methanol extract of this species in ethanomedicine providing lead for antifungal and antimicrobial for above strains.

\section{References}

1. Almeida, S.M. (1990). Flora of Savantwadi, MaharashtraVol. 1. Indian Journal of Economic and Taxonomic Botany Additional Series.

2. Mishra, D.K. \& N.P. Singh (2001). Endemic and Threatened Flowering Plants of Maharashtra. Botanical Survey of India, Calcutta

3. Patil S.V., R. P. Mane, S. D. Mane, P. V. Anbhule, V. B. Shimpale (2016) Chemical Composition of the Essential Oil from Seeds of Pinda concanensis: An Endemic Plant from Western Ghats of India Int. J. Pharm. Sci. Rev. Res., 41(1): 49-51

4. Carbonnier, J. and D. Molho. (1977). Contribution phytochimique a letude de la position systamatique de Vanasushava pedata (Wight) Mukherjee et Constance (Heracleum pedatum Wight). Bull. Mus. Hist. Nat

5. Gosavi K.V.C., Neeta A. Jadhav \& S.R. Yadav (2016) Cytological Studies in four Endemic Genera of Apiaceae. Taiwania 61(4):314-318

6. Dubey N. K., Kumar R., and Tripathi, P., Global Promotion of herbal medicine; India's opportunity. Curr.Med 2004; 86:37-41.

7. WHO mental health Global Action Program (mega) World Health Organization, Geneva, Switzerland; 2002

8. Gupta R.K., S Chandra, V. Mahadeven chemical composition of Sphaeranthus indicus Linn India J Pham1867; 29: 47-48.

9. Heisig P (2001) Inhibitors of bacterial topoisomerases: mechanisms of action and resistance and clinical aspects. Planta Med. 67, 3-12. 
10. Basarkar U.G. et al., (2012). Preliminary phytochemical screening of Leonotis nepetaefolia an ayurvedic herb. BIONANO FRONTIER VOL. 5 (2 - II) :239-243

11. Swarnalatha L. and P. Neelakanta Reddy.,2009. Antimicrobial, antidiarrhoeal and analysis of phytochemical constituents of Sphaeranthus amaranthoides Indian Journal of Science and Technology Vol.2 No (3): 45-48

12. Mukherjee, P. K. and L. Constance. 1986. A New Disposition of the South Indian Heracleum concanense Dalzell (Umbelliferae). Kew Bull. 41: 223-229.

13. Mukherjee, P. K. and L. Constance. 1974. Vanasushava, an Old South Indian Umbellifer Renamed Author(s): Prasanta PK. Mukherjee and Lincoln Constance. Kew Bull. 29: 593596

14. Guyot, M. 1978. Contribution phytodermique (types stomatiques, morphologie des poils) a l'etude du Vanasushava pedata (Wight) Mukherjee et Constance, Ombellifere du Sud de l'Inde. Rev. Gen. Bot.85: 11-19.

15. Irwin, S.J. and D. Narasimhan. 2011. Endemic genera of Angiosperms in India: A Review. Rheedea 21: 87-105.

16. Mohanan, N. and G. Pimenov. 2007. Sivadasania, A New Genus of Apiaceae from Peninsular India. Botanicheskii Zhurnal. Moscow \& Leningrad. 92: 900-904.
17. Mukherjee, P.K. 1988. Vanasushava pedaita (Wight) P.K Mukh. \& Constance. In: Nayar M. P. and Sastry, A. R. K. (ed.), Red Data Book of Indian Plants. Vol. 2. Botanical Survey of India, pp. 30.

18. Nayar, M.P. 1996.Hot spots of endemic plants of India Nepal and Bhutan. Tropical Botanic Garden and Research Institute, Thiruvananthapuram

19. Mukherjee, P.K. and L. Constance. 1986a. A New Disposition of the South Indian Heracleum concanense Dalzell (Umbelliferae). Kew Bull. 41(1): 223-229.

20. Cauwet-Marc, A.M. 1977. Anatomie comparee du fruit de Vanasushava pedata (Wight) Mukherjee et Constance et de quelques genres voisins. Newsletter Umbell. 2: 30-34

21. Farnsworth Norman R. (1966) Biological and Phytochemical Screening of plants. Journal of Pharmaceutical Sciences 55(3):225-276.

\section{Cite this article as}

Hemantkumar A. Thakur. Phytochemical Screening and Antibacterial, Antifungal activity of Pinda concanensis (Dalzell) P.K. Mukh. \& Constance (Apiaceae) an endemic plant from Nasik District (M.S.) India. Annals of Plant Sciences 6.12 (2017) pp. 1886-1892. doi: http://dx.doi.org/10.21746/aps.2017.6.12.15 